\title{
Building an Integrated Mining Licensing System in Order to Preserve the Environment in Indonesia
}

\author{
Muhamad Azhar ${ }^{1,2 *}$,Putut Suharso $^{3}$, Budi Ispriyarso $^{1}$, Agus Purnomo $^{1}$, Suhartoyo \\ Suhartoyo $^{1}$, and Sukirno Sukirno ${ }^{1}$ \\ ${ }^{1}$ Faculty of Law, Diponegoro University, Prof. H. Soedarto SH street, Semarang 50275 Indonesia \\ ${ }^{2}$ Administrative Law Study Center, Diponegoro University, Prof. H. Soedarto SH street, Semarang \\ 50275 Indonesia \\ ${ }^{3}$ Departement of Library and Information Science, Diponegoro University, Prof. H. Soedarto SH \\ street, Semarang 50275 Indonesia
}

\begin{abstract}
The consideration of economic interests (economic approach) has led to various problems in building a licensing system. In addition to economic sentiment, there are also sectoral ego of technical institutions and inconsistencies of various mining laws and regulations in the context of environmental preservation. The research aims to find solutions for the development of integrated licensing in the field of mining in order to maintain the sustainable environment in Indonesia. This research method of writing is a legal research. The research used statutory approach approach, comparative approach. After that, the study was analyzed using cystensis analysis. The results of the research indicate that building an integrated mining licensing system in the framework of environmental maintenance can be done through the synchronization of legislation related to mining licensing. Singronization focuses on mining which has a direct relationship with sustainable environmental maintenance and an integrated licensing institutional model in the sustainable mining field.
\end{abstract}

\section{Introduction}

Research on development in developing countries has become a hot issue from the past until now. Large losses for the country that provide flexibility for developed countries. It is undeniable that the income from the process and output is very promising. But whose profits are made, the big company or only a few people in the government who ignore what happens after exploitation and exploration does not continue.[1]

Article 33 of the 1945 Constitution is always buzzing and is the basis for management in Indonesia. This is a different and more motivated issue. Indeed, we can use it in a number of economic aspects that relate or are used for the environment or natural

\footnotetext{
* Corresponding author:azharundip $\underline{@ \text { gmail.com }}$
} 
resourcesto always override environmental aspects. The environment by some anthropocentrists is considered as an object that is very effective because humans are considered to be the highest being from other abiotic creatures (inanimate objects such as mountains, forests, rivers,etc.) and also biotic (living things such as animals and plants)) There is no meaning what so ever that happens later or the next generation.

Likewise, environmental issues always arise if there has been damage and / or pollution or then there is a victim of a business activity. The pre-emptive and preventive aspects are always ignored to produce products that are good and economical and make money fast rather than the aspects of mitigation and recovery so that the damage can be more widespread and uncontrollable. No matter how good an attempt to restore a damaged or polluted environment will not return to the position of the previous environmental quality [2]. Even though the tightening is related to licensing. As in the field of mineral mining licensing in Indonesia, it is still considered unsatisfactory. The 2017 Resource Governance Index report issued by the Natural Resource Governance Institute (NRGI) gives a value of 37 out of 100 points to Indonesia (Figure. 1 and Figure. 2). This position is still lagging behind countries in the Asia Pacific region.

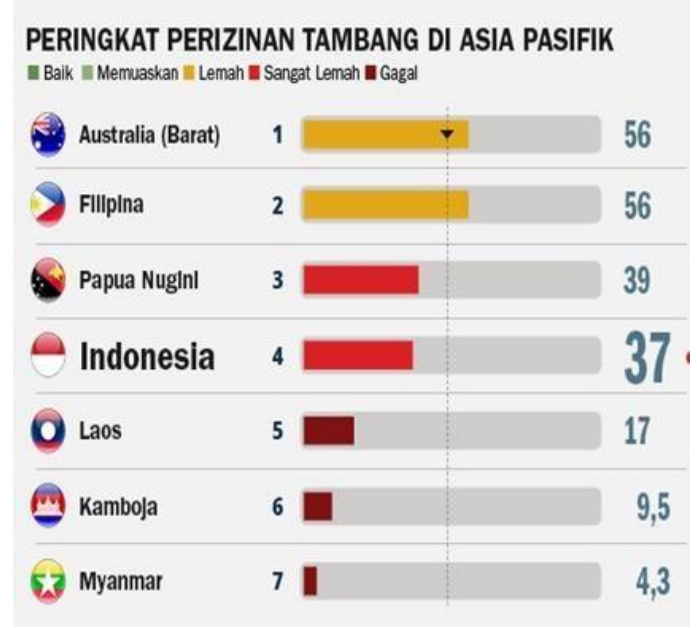

Fig. 1. Licensing rating for mining in Asia Pacific: 4he 2017 Resource Governance Index Report issued by the Natural Resource Governance Institute (NRGI)

\begin{tabular}{|c|c|}
\hline \multicolumn{2}{|c|}{ INDONESIAN REPORT } \\
\hline 10 components of licensing & Assessment \\
\hline Backup data transparency & 77 \\
\hline Cadastre & 0 \\
\hline Pre-licensing regulations & 75 \\
\hline Pre-licensing practices & 0 \\
\hline Post-licensing regulations & 75 \\
\hline Post-licensing practices & 67 \\
\hline Rules for disclosure of financial interests & 75 \\
\hline Openness practices of financial interests & 0 \\
\hline Contract disclosure regulations & 0 \\
\hline Contract openness practices & 0 \\
\hline
\end{tabular}

Fig. 2. 2017 Resource Management Index Report issued by the Natural Resource Governance Institute (NRGI).

The position of mining law and environmental law as a multidisciplinary science among 
other sciences such as environmental engineering, environmental health, environmental biology, environmental chemistry and other related sciences is felt too late to follow the acceleration of these sciences and only as sweeteners and complementary objects incarnate. through weak enforcement of environmental law in Indonesia. Especially the weak role of legal instruments in controlling the rate of environmental destruction.

The history of Indonesian mining began with Freepot's first management concession rights with unlimited exploitation and could be extended at any time to make Indonesia economically and ecologically disadvantaged. This was driven by the President's policy in the New Order era with the pretext for development that made us lulled. The New York Agreement agreed upon after the fall of President Soekarno and then replaced by President Soeharto opened a wide door for the freedom of exploitation of Indonesia's natural resources. And we should be grateful after more than 30 years, the fresh air came from the issuance of the Law in the mining sector, which requires ownership of mining business licenses for implementing concession rights. Even the latest $51 \%$ freeport stock development has been controlled by the Indonesian government.

On the other hand, the control of the mine has not been accompanied by an integrated licensing arrangement in the mining sector. Integrated licensing in the mining sector is interpreted as a way to halt the environmental damage that occurs. There must be an effort to stop continuous damage from the result of mining activities of all types of mining materials [3]. This was done so that the loss of a country because the environmental chaos did not occur continuously. The avoidance of these losses is an ideal in order to realize good governance and clean government is a fundamental demand for the global community order. In the state of welfare law adopted by Indonesia, the main task of the government is to realize the goals of the country, one of which is through public service and the participation of the government in the social life of the community. One of the government authorities is the implementation of the mining permit system in the context of maintaining the environment. Licensing is termed lincence, permit (english); vergunning (dutch). Permits are only government authorities and monopolies. There are no other institutions outside the government that can grant mining permits in Indonesia [4].

The implementation of the mining permit system in the context of maintaining the environment is a preventive juridical government tool, and is used as an administrative instrument to control behavior in the context of environmental protection and management [5]. Licensing in the mining sector as a form of the application of laws related to mining, of course must be carried out in accordance with the law that is integrated. Integrated licensing in the field of mining in the context of maintaining the environment is not only about technical administration (procedures, terms, time and costs). It also relates to aspects of substance licensing in other fields, especially the environment itself [6]. The licensing of all environmental sectors, such as mining, forestry, plantations and other fields, must be based on environmental law as an umbrella.

\section{Materials and Methods}

This research is a legal research from the aspect of social perspective. This legal research identifies the norms of regulations or laws that apply. The use of relevant legal research is to understand legal issues more thoroughly [7]. The approach used is socio legal but also legal approach, conceptual approach, in this case, the law is seen as a space for the process of scientific study in order to find the truth. The proof through the articles of the positive law regulations and the existing literature review from the existing research are described in a descriptive qualitative manner. 
Thus this paper is not limited by the mere model of thinking in seeing the problem. The socio-legal study domain conceptualizes law as a norm and also behavior, the law is seen only as concrete, written, approved and issued by the competent institution which in its work is influenced by various other factors such as economic, political, social, cultural, religious, etc. [8], [9]. In this case, socio-legal research leads to a more comprehensive, intact, and not textual understanding of the law. Want to know whether the rule is effective, positive, productive, or even annoying and destructive[10].

\section{Results and Discussions}

The results of the study will describe two main things as the main points to answer how solutions for the development of integrated licensing in order to maintain the sustainable environment in Indonesia. These questions will be answered with two main discussion topics, namely: The meaning and nature of integrated licensing in the mining business environment; and the second is the synchronization of legislation in the mining permit system in the context of environmental preservation in Indonesia.

\subsection{The Meaning and Nature of Integrated Licensing in the Field of Environment}

Melvin Jager [11] argues for the term permission in a broad sense, while permission in the narrow sense is called "permission" only. Permits (in the strict sense) are further distinguished by other forms of licensing such as dispensation, concessions, recommendations, sign-ups, letters of approval, and registration. Permission in the broadest sense (licensing) is an agreement from the authorities based on laws or government regulations, to in certain circumstances deviate from the prohibition provisions of the legislation [12]. Permits as legal acts of one-sided administration apply the rules in concrete terms based on the requirements and procedures stipulated in the prevailing laws and regulations. Environmental permits are agreements issued by the government in the context of environmental management $[13,14]$. Initially environmental management was carried out through the sectoral power paradigm of each agency. Furthermore, it is not coordinative and not integrated, with submission to the legal system that is sectoral and not comprehensive (comprehensive law). This approach is not appropriate, because the nature and nature of the environment is comprehensive and one another, connected to each other in accordance with the principle of the environment itself, "everything is connected to everything else", as well as the nature of the mobile or its motion, "everything must go somewhere".

Based on this thought, it needs an integrated legal basis for all mining management in the context of environmental preservation. Therefore, for all sectors and institutional units that are competent in mining management, it should be based on the principles of integration and coordination, so that they are not sectoral, but integrated and coordinated. Mining Business Permit in Law Number 4 of 2009 concerning Mineral and Coal Mining (Minerba Law), Article 1 number 7. Mining Business License (Izin Usaha PertambanganIUP) is a license to conduct mining business. Mining activities are regulated in Law Number 4 of 2009 concerning Mineral and Coal Mining (Minerba Law).

To more detail the implementation of this Law, it was re-reduced in the form of Government Regulation (Peraturan Pemerintah-PP), one of which was Government Regulation No. 23 of 2010 concerning the Implementation of Mineral and Coal Mining Business Activities. PP 23/2010 has undergone four changes. First, Government Regulation 
Number 24 of 2012 concerning the First Amendment to the Implementation of Mineral and Coal Mining Business Activities. Secondly, Government Regulation Number 1 of 2014 concerning the Second Amendment to the Implementation of Mineral and Coal Mining Business Activities. Third, Government Regulation Number 77 of 2014 concerning the Third Amendment to the Implementation of Mineral and Coal Mining Business Activities. Fourth, Government Regulation Number 1 of 2017 concerning the Fourth Amendment to the Implementation of Mineral and Coal Mining Business Activities.

Based on the Government Regulation, mining commodities are grouped into 5 categories: Radioactive minerals include: radium, thorium, uranium; Metal minerals include: gold, copper; Nonmetallic minerals include: diamonds, bentonite; Rocks include: andesite, clay, urug soil, excavated gravel from a hill, river gravel, sand sand; and Coal, among others: asphalt rock, coal, peat.

Currently more well-known mining activities are mining for metal mineral commodities, among others: gold, copper, nickel, bauxite and coal commodities. In addition to these main mineral commodities and coal, rock commodities play an equally important role, especially in providing material support for infrastructure development, including: the establishment of road infrastructure, housing construction and office buildings. The terminology of class $\mathrm{C}$ excavation material previously regulated in Act No. 11 of 1967 concerning Basic Mining Conditions has been amended based on Law Number 4 of 2009 , to become a rock, so that the use of the term C class material is no longer appropriate and replaced with rock.

\subsection{Synchronization of Laws and Regulations for the Environmental Licensing System in Indonesia}

One form of permit in the mining sector is the existence of a Mining Business License based on Law Number 4 of 2009 concerning Mineral and Coal Mining (the Minerba Law). In Article 1 number 7. "Mining Business Permit (IUP) is a permit to conduct mining business. Mining activities are regulated in Law Number 4 of 2009 concerning Mineral and Coal Mining (Minerba Law). To more detail the implementation of this Law, it was rereduced in the form of Government Regulation (PP), one of which was Government Regulation No. 23 of 2010 concerning the Implementation of Mineral and Coal Mining Business Activities.

PP 23/2010 has undergone four changes. First, Government Regulation Number 24 of 2012 concerning the First Amendment to the Implementation of Mineral and Coal Mining Business Activities. Secondly, Government Regulation Number 1 of 2014 concerning the Second Amendment to the Implementation of Mineral and Coal Mining Business Activities. Third, Government Regulation Number 77 of 2014 concerning the Third Amendment to the Implementation of Mineral and Coal Mining Business Activities. Fourth, Government Regulation Number 1 of 2017 concerning the Fourth Amendment to the Implementation of Mineral and Coal Mining Business Activities.

Based on the Government Regulation, mining commodities are grouped into 5 categories: Radioactive minerals include: radium, thorium, uranium; Metal minerals include: gold, copper; Nonmetallic minerals include: diamonds, bentonite; Rocks include: andesite, clay, urug soil, excavated gravel from a hill, river gravel, sand sand; and Coal, among others: asphalt rock, coal, peat. Currently more well-known mining activities are mining for metal mineral commodities, among others: gold, copper, nickel, bauxite and coal commodities. In addition to these main mineral commodities and coal, rock commodities play an equally important role, especially in providing material support for infrastructure development, including: the establishment of road infrastructure, housing 
construction and office buildings. The terminology of class $\mathrm{C}$ excavation material previously regulated in Act No. 11 of 1967 concerning Basic Mining Conditions has been amended based on Law Number 4 of 2009 , to become a rock, so that the use of the term C class material is no longer appropriate and replaced with rock.

The important things related to Mining Business Permit (IUP) are as follows: 1). Types of Mining Business Permits (IUP) In Article 36 of Law Number 4 of 2009 concerning Mineral and Coal Mining, Mining Business Permits (IUP) divided into 2 (two) stages, namely:

a. Exploration Mining Business Permit (IUP) This is the first stage of permit issuance which includes general investigation, exploration and feasibility studies. For IUP exploration for metal mineral mining is given within a period of 8 (eight)years.

b. Mining Business Permit (IUP) Production Operation Is a permit covering construction activities, mining, processing and refining, as well as transportation and sales. IUP Production operations for metal mineral mining are given in a maximum period of 20 years and can be extended twice for 10 year seach.

The enactment of Environmental Protection and Management Law (UU-PPLH= Undang-undang Perlindungan dan Pengelolaan Lingkungan Hidup), has legal implications for the licensing system in Indonesia. All laws and regulations in the environmental field may not conflict with UU-PPLH as a legal norm for "umbrella or guidelines". Law No. 32 of 2009 as a tool for discipline, balance guard and development catalyst. UU-PPLH should be a breakthrough for environmental sustainability and sustainability to realize sustainable development in Indonesia.

Based on the concept of an integrated environmental licensing system, all laws and regulations in the environmental field should be in sync. This is a major step towards an integrated environmental licensing system in Indonesia. But at this time, precisely the opposite. Licensing in each sector such as forestry, plantation and mining is regulated by a separate law. In addition to the issue of the substance of the licensing system, the regulation of each sector in a separate law increasingly fosters a "sectoral ego" attitude in the implementation of licensing. Laws in Indonesia tend to be sectoral because the draft bill comes from their respective ministries. As a result the Forestry Law belongs to the Ministry of Forestry. Mining Law of the mining ministry. The Environmental Law of the Ministry of Environment, and so on. Implementation overlaps and wins each other. Synergistic desire is far from reach, natural resource management shows winning defeat. Each party feels that they have full authority to organize permits, without having to coordinate.

Adherence to the regulation of sectoral fields, the scope of the implementation of sectoral sector regulations should be part of UU-PPLH. The problem is that the Law on PPLH deals with the same level of regulation, namely the Forestry Law, the Plantation Law and the Mining Law and other sectors which are also regulated by the Law. Even the mining sector itself has 3 (three) fields, each of which is regulated by the Law itself. Based on the 1945 Constitution, "each draft law is discussed by the People's Representative Council and the President to obtain a collective agreement (Article 20 paragraph 2). The President endorsed a bill that had been jointly agreed to become a law (Article 20 paragraph 3). So between the one law is not higher than other laws based on Law No. 12 of 2011 concerning the Establishment of Legislation, the hierarchy of statutory regulations is (Article 7 paragraph 1): the 1945 Constitution of the Republic of Indonesia; Legislation / Government Regulation in Lieu of Law; Government regulations; Presidential decree; Local regulation.

Content material that must be regulated by law contains the following matters. First, to look further at the provisions of the Constitution of the Republic of Indonesia in 1945 which include: human rights; the rights and obligations of citizens; the implementation and 
enforcement of state sovereignty and the distribution of state power; territory of the country and regional division; nationality and residence; and state finances. Second, it is ordered by a law to be regulated by law (Article 8). According to Hans Kelsen, the basic norm of a positive legal order is nothing but a fundamental rule about making various norms from the positive legal order.

Basic norms according to Kelsen [15] are legal sources, meaning that they determine the validity and effectiveness of law, such as the Law. Kelsen also said, any "higher" legal norms are "sources" of lower legal norms. This means that lower regulations must be based on higher regulations, up to basic (fundamental) norms. As further said by Kelsen, the establishment of legal norms is usually the application of higher legal norms, which govern their formation, and the application of higher legal norms is usually the formation of lower legal norms determined by higher legal norms. that. Hans Kelsen's [16] opinion if it is reinterpreted in the Law as the main provision for other sectoral laws, there are two meanings. The first meaning, in terms of substance, the Forestry, Plantation and Mining Law Act actually includes aspects of the environment that are regulated by UU-PPLH, because the scope of the Law on PPLH includes the space, the Republic of Indonesia Unitary State. in carrying out its sovereignty, right of rights and jurisdiction. Therefore, the Law on PPLH substantially has a higher position compared to the Forestry Law, the Planting Law and the Law on Mining. Secondly, the formal position of each law is equal, so that each other is not higher. As contained in the 1945 Constitution and Law No. 12 of 2011, all laws are a joint product between the DPR and the President. Therefore, UU-PPLH is not higher than the Forestry, Plantation and Mining laws. However, at the practice level, each sector forms implementing regulations and ignores environmental laws. The Ministry of Justice feels that it has the same legal power and can exercise its authority in accordance with the provisions of the Law in each sector. This is what has happened in the implementation of environmental environmental licensing systems in Indonesia.

Based on the scope of the integrated licensing system in the environment, the government regulations must include permits in the environmental sector. First, it does not only regulate environmental permits, but also includes permits in the fields of forestry, plantation, mining and fisheries/marine affairs and all other environmental permits. Second, the integrated licensing system needs to avoid "over protection". The balance between economic, environmental and social interests will make the regulation of the integrated licensing system an instrument to realize sustainable development. The government's attention to the social environment has a positive impact on developing the capacity of the social structure of the community [17-19]. In accordance with the provisions of Article 44 of the Law on PPLH which stipulates that each drafting of legislation at the national and regional levels is mandatory pay attention to the protection of environmental functions and the principle of environmental protection and management in accordance with the provisions stipulated in this Law. Article 6, specifically paragraph (2) of Law No. 12 of 2011 confirms that the principle of alloying in the context of the compilation of environmental-based laws and regulations is a "necessity". Synchronization of environmental-based legislation regulations in the integrated licensing system in the environment does not mean prioritizing conservation interests. Indeed in the context of sustainable development it should be avoided, because it will create "stagnation" of the development process in Indonesia.

Third, the synchronization to realize the integrated legal licensing system in the environment must be imbued with the principles of sustainable development. The principles of sustainable development are used as the basis for the substance of the regulation of the integrated licensing system in the environment. The principles are the principles of intergenerational equity, the principle of justice in one generation (Intragational Equity), the 
principle of early prevention (Pre-Zionary Principle), the principle of the protection of Biodiversity Conservation [20]. The principle of environmental cost internalization The environmentally sound development regulation has not run optimally as expected. Efforts to realize this must be carried out by various parties, among others, by encouraging all parties, both government and society to play an active and independent role in environmental development, based on the understanding that humans need to be improved in their position, from environmental damage be the savior of the environment, environmentalists and environmental safeguards.

The integration of sustainable development principles in licensing activities in Indonesia is implicitly regulated in the 1945 Constitution. According to Jimly Asshiddiqie, Article 33 paragraph (4) of the 1945 Constitution confirms the existence of sustainability principles contained in economic democracy, "the national economy is organized based on democracy economy with the principle of sustainable, environmentally sound Integration of the principles of sustainable development into the environmental permit system, is expected to meet the needs of the present and not threaten the sustainability of environmental functions for the needs of future generations. To realize this principle, the principle of early prevention, the principle of biodiversity and the internalization of environmental costs must be done first.

Based on the articles in the PPLH Law, the overall principles of sustainable development already exist, namely through KLHS (kajian lingkungan hidup strategis). KLHS as an instrument to realize the principles of sustainable development. Article 1 number 10 UU-PPLH, namely: Strategic environmental study, hereinafter referred to as KLHS, is a systematic, comprehensive, and participatory analysis series to ensure that the principles of sustainable development have become basic and integrated in the development of an area and/or policies, plans and/or programs.

The integration of the principles of sustainable development in environmental regulations, was carried out through KLHS. KLHS as an instrument to prevent pollution or damage to the environment, is a form of integration of the principles of sustainable development. Then the SEA as a guideline and outlined in the long-term, medium-term development plan, spatial plan. The integration is outlined in the arrangement and implementation of the licensing system. KLHS is ultimately realized in the decision making regarding environmental permits.

\section{Conclusion}

Based on the overall discussion and the descriptions. The results of this research indicate that building an integrated mining licensing system in the framework of environmental maintenance can be done through the synchronization of legislation related to mining licensing. Singronization focuses on mining which has a direct relationship with sustainable environmental maintenance and an integrated licensing institutional model in the sustainable mining field.

\section{References}

1. J. Martinez-Alier. J. Hazard. Mater 86, 1 (2001)

2. S. Sauvé, S. Bernard, and P. Sloan. Environ. Dev 17 (2016)

3. R. Sousa, M. Veiga, D. Van Zyl, K. Telmer, S. Spiegel, and J. Selder. J. Clean. Prod 19 (2011) 
4. B. Bhasin and S. Venkataramany, Mining Law and Policy in Indonesia: Replacing the (2007)

5. G. Hilson and V. Nayee. Int. J. Miner. Process 64, 1 (2002)

6. S. Rahardjo, Membangun dan merombak hukum indonesia [build and overhaul indonesian law]. (Yogyakarta, Genta Publishing, 2009)

7. I. Dobinsori and F. Johns, Legal research as qualitative research in research methods for law, (Edinburgh, Edinburgh University Press, 2017)

8. J. P. Lomio, H. S. Spang-Hanssen, and G. D. Wilson, Legal research methods in a modern world: a coursebook (DJØF Publishing, 2011)

9. A. C. M. Meuwese and S. van Voorst, Regulatory impact assessment in legal studies," (Handbook of Regulatory Impact Assessment, Cheltenham, Edward Elgar, 2016)

10. A. Grifflths, Using ethnography as a tool in legal research: an anthropological perspective, (Theory and Method in Socio-Legal Research, Portland, Hart Publishing, 2005)

11. M. Jager, Licensing Law Handbook, 2008-2009 ed. (New York, Clark Boardman Callaghan, 2008)

12. M. Azhar. J. Notarius 9, 2 (2015)

13. M. Azhar, S. Suhartoyo, P. Suharso, V. E. Herawati, and N. Trihastuti. E3S Web Conf. SCiFiMaS 47 (2018)

14. M. Azhar, S. Suhartoyo, L. T. Alw, P. Suharso, and V. E. Herawati. E3S Web Conf. SCiFiMaS 47 (2018)

15. H. Kelsen, General theory of law and state. (Translated by Anders Wedberg, New Jersey, Lawbook Exchange, 2009)

16. J. von Bernstorff, The Public International Law Theory of Hans Kelsen: Believing in Universal Law (Cambridge, Cambrige University Press, 2011)

17. P. Suharso and S. Sarbini. E3S Web Conf. SCiFiMaS 47 (2018)

18. P. Suharso, B. Sudardi, S. T. Widodo, and S. K. Habsari. IOP Conf. Ser. Earth Environ. Sci 116, 1 (2018)

19. P. Suharso, B. Sudardi, S. T. Widodo, and S. K. Habsari. E3S Web Conf. SCiFiMaS 47 (2018)

20. H. Briassoulis, Policy integration for complex environmental problems: the example of Mediterranean desertificatio (Routledge, 2017) 